\title{
Reforming School-Based Curriculum and Cultivating Students' Core Literacy: Tak- ing Chengdu Qizhong Experimental School as an Example
}

\author{
Liping $\mathrm{Xu}$ \\ Chengdu Qizhong Experimental School, Chengdu, China
}

\begin{abstract}
The exploration of school-based curriculum with the core literacy concept is a new trend in the world's education reform and development. Starting from the background of core literacy school-based curriculum construction, combined with the school-running characteristics and concepts of Chengdu Qizhong Experimental School, we carried out the practical exploration of school-based curriculum, determined the curriculum objectives, and constructed a school-based curriculum system generated by core literacy. Through the reform of classroom teaching mode, the construction of learning groups, and the transformation of student learning methods, the core literacy of students has been cultivated.
\end{abstract}

Sci Insigt Edu Front 2019; 3(2):311-321.

Doi: 10.15354/sief.19.ar099

Keywords: Core Literacy; School-Based Curriculum; Student Development

Correspondence to: Liping Xu, Chengdu Qizhong Experimental School, Chengdu, China. Email:631161070@qq.com.

Conflict of Interests: None. 
I N September 2016, China announced the China Student Development Core Litera$c y$, which aroused widespread public attention. For the first time, this document has carried out systematic and authoritative discussion on what kind of talents to be trained and how to cultivate them from the perspective of "core literacy". The promulgation of this document has critical guiding significance for the current reform and development of China's basic education.

As a highly dynamic and innovative school, Chengdu Qizhong Experimental School has long been promoting quality education with people-oriented and studentbased focuses, and to comprehensively develop and cultivate students 'abilities. What kind of people is cultivated and how are they cultivated? What are the connotations and standards for cultivating student literacy? How to develop students' ability to learn for life? These have always been the core concerns in the school management process.

After the announcement of the core literacy of student development, the school pays more attention to the new round of school-based curriculum construction and teaching reform led by core literacy, and finds the carrier, method and strength of core literacy in the Experimental School of Chengdu Qizhong, forming a school-based distinctive curriculum system (Table 1). We have accumulated the experience and path of cultivating students' core literacy through the reform of school-based curriculum in the context of China's national education, and promoted the professional growth of teachers and the overall development of students. Such reform and exploration is not only important for the development of the school, but also a microcosm of China's current education reform, with important theoretical and practical value.

\section{The Background of the Core Literacy School-Based Curriculum Construction}

\section{Time Background}

In the context of globalization, informatization and the era of knowledge economy, UNESCO published the report "Education: Wealth Contains It", and the European Union (EU) has developed the Core Literacy of Lifelong Learning: European Reference Architecture. The International Organization for Economic Co-operation and Development (OECD) has carried out a research project on the definition and selection of literacy (European Commission, 2012). The United States proposed that learning and innovation literacy, information, media and technical literacy, and life and professionalism are key literacy for students to prepare for the 21 st century. Many countries, such as Germany, Norway, Sweden, Finland, Denmark, and Poland, have also regarded core literacy as an important source of educational goals and have planned them into an important curriculum framework for learning to promote curriculum reform (Cai, 2015).

In China, the Ministry of Education issued the "Opinions on comprehensively deepening the reform of curriculum reform and establishing the fundamental tasks of ethics and educating people" in 2014, proposing that "the Ministry of Education will 
Table 1. School-Based Curriculum System of Chengdu Qizhong Experimental School.

\begin{tabular}{|c|c|c|}
\hline Type & Course Core & Specific Implementation \\
\hline $\begin{array}{l}\text { Etiquette } \\
\text { course }\end{array}$ & $\begin{array}{l}\text { Taking human } \\
\text { education as the } \\
\text { core }\end{array}$ & $\begin{array}{l}\text { Use morning meetings or class meetings to educate civilized } \\
\text { etiquette and character development; open etiquette, physi- } \\
\text { cal and international understanding education courses. }\end{array}$ \\
\hline $\begin{array}{l}\text { Life } \\
\text { course }\end{array}$ & $\begin{array}{l}\text { Focusing on } \\
\text { cultivating inde- } \\
\text { pendent living } \\
\text { ability }\end{array}$ & $\begin{array}{l}\text { Study life skills (sleeping indoors, carry out dumplings, } \\
\text { Yuanxiao and other activities); experience the fun of planting } \\
\text { and breeding (planting vegetables on campus plantations; } \\
\text { feeding small goldfish, silkworms, and entering the red scarf } \\
\text { farm to take care of the white rabbits); Carry out labor educa- } \\
\text { tion. }\end{array}$ \\
\hline $\begin{array}{l}\text { Artistic } \\
\text { course }\end{array}$ & $\begin{array}{l}\text { Focus on culti- } \\
\text { vating individu- } \\
\text { ality }\end{array}$ & $\begin{array}{l}\text { According to different age groups, different art courses are } \\
\text { offered: practicing martial arts and xylophone in the first and } \\
\text { second grades; adding calligraphy courses in the third and } \\
\text { fourth grades, electing tie dyes and African drums; learning } \\
\text { clarinet in the fifth and sixth grades, electing golf, football, } \\
\text { basketball Volleyball; ceramics from the first to the sixth } \\
\text { grade. And a variety of sunny sports and cultural festivals; } \\
\text { student art exhibitions. }\end{array}$ \\
\hline $\begin{array}{l}\text { Activity } \\
\text { course }\end{array}$ & $\begin{array}{l}\text { Focus on the } \\
\text { activity practice } \\
\text { experience }\end{array}$ & $\begin{array}{l}\text { The first, second and third grades read classical poetry per- } \\
\text { formances; fourth, fifth and sixth grade study tours; school- } \\
\text { wide science and technology activities monthly series activi- } \\
\text { ties: ship model, model aircraft, car model, Rubik's cube } \\
\text { competition; technology caravan into campus activities. }\end{array}$ \\
\hline $\begin{array}{l}\text { Learning } \\
\text { course }\end{array}$ & $\begin{array}{l}\text { Focusing on } \\
\text { enhancing aca- } \\
\text { demic literacy }\end{array}$ & $\begin{array}{l}\text { In addition to the guidance of teachers' classroom teaching, } \\
\text { they also carry out related academic competitions to promote } \\
\text { the improvement of students' academic literacy, such as } \\
\text { hard pen calligraphy competition; mathematics week activi- } \\
\text { ties (bead mental arithmetic competition, "digital } \\
\text { Huarongdao" competition, three-dimensional graphic group } \\
\text { activities); English speaking contest; scientific knowledge } \\
\text { contest. The third and fourth grade elective STEAM courses. }\end{array}$ \\
\hline $\begin{array}{l}\text { Vitality } \\
\text { course }\end{array}$ & $\begin{array}{l}\text { Focus on life } \\
\text { vitality education }\end{array}$ & $\begin{array}{l}\text { Swimming courses in the second to fourth grades; moral } \\
\text { education series activities (firefighting, earthquake drills; } \\
\text { safety lectures on campus, transportation, etc.; military train- } \\
\text { ing; small cadre training, etc.). }\end{array}$ \\
\hline $\begin{array}{l}\text { Local } \\
\text { course }\end{array}$ & $\begin{array}{l}\text { Inheriting re- } \\
\text { gional culture as } \\
\text { the core }\end{array}$ & $\begin{array}{l}\text { In the fourth grade, the root-catching fish show was held; in } \\
\text { the fifth grade, he entered the top ten celebrity activities in } \\
\text { Sichuan province. }\end{array}$ \\
\hline
\end{tabular}

organize research and put forward the core literacy system for students in each semester, and clarify that students should have The necessary character and key ability to meet the needs of lifelong development and social development", the report on "China Student Development Core Literacy" was released in September 2016. Core literacy is centered on cultivating "all-round development people". It is divided into three aspects: 
cultural foundation, independent development and social participation. It comprehensively includes six aspects: humanistic heritage, scientific spirit, learning to learn, healthy living, responsibility, and practice innovation (Beijing Normal University Research Group, 2016).

The core literacy of Chinese students' development is rooted in the soil of Chinese excellent traditional culture. From the experience and deep reflection of the basic education curriculum reform, it draws rich nutrition, gains important enlightenment, and closely follows the reality of Chinese students' development. It starts from the characteristics and needs to shape the soul of Chinese education.

\section{School Reform Background}

"Setting the development of both teachers and students as the main body, so that help each student achieve goals, jointly lead the values, and support high-quality courses" is the core concept of the development of Chengdu Qizhong Experimental School. We pay attention to the construction of integrated courses and special courses. On the basis of inheriting the existing experience of running schools, it not only realizes the educational goals of the national curriculum, but also fully demonstrates the characteristics of the curriculum implementation of the school itself.

Based on the new situation, the state proposes to cultivate students' core literacy, which has more advanced guiding significance for the reform of the curriculum system. The school transforms the unified requirements of the core literacy of Chinese students into the concrete content of the school-based exploration and education process of the Chengdu Qizhong Experimental School. With the core purpose of cultivating students' core literacy, the school develops curriculum resources suitable for the students of the school.

\section{Exploration of School-based Curriculum for the Cul- tivation of Students' Core Literacy}

\section{The Goal of School-Based Curriculum Construction}

\section{Focus on the core literacy of students and realize the effective integration of school-based curriculum construction and peo- ple education.}

We continue to explore and practice on the basis of clear direction. Under the premise of fully using the courses required by the state, the school takes the core literacy of students as the basis and starting point for the development of school-based curriculum, and offers special school-based curriculum to enrich students' cultural vision and real- 
ize effective integration of specific educational goals and tasks at all grades and disciplines with school-based curriculum construction.

\section{Combine the school-running philosophy to cultivate modern people with Chinese soul and international competitiveness.}

With reference to the core literacy of Chinese students, according to the age characteristics of the students and the school culture, the students' training objectives are refined as "cultivating modern people with Chinese soul and international competitiveness". Through the setting of school-based curriculum, it is necessary to cultivate students with the spirit of unity, peace-loving, diligence and courage, self-improvement, and the spirit of progress with times, pioneering and enterprising, seeking truth and being pragmatic, and courageously fighting for the times. This kind of spirit is a gathering of strength, is to revitalize and enhance the soul of the school, that is, we must cultivate students with spirits of social responsibility, citizen consciousness, national identity, international understanding, humanistic heritage, scientific spirit, aesthetic taste, physical and mental health, and practical innovation.

The school's training objectives clearly stipulate that students should have the world's vision, that is, they should have the following three qualities, 1) Global vision: absorb the excellent cultural achievements of all nations in the world with an open mind. 2) Global skills: learn to master international communication and language skills, and integrate with internationalization in terms of perspective, language, culture, knowledge, ability, etc. 3) Global quality standards: modern students with international competitiveness must also develop innovative models to enable them to solve problems, obtain information, communicate, strengthen teamwork cooperation, and self-plan and management.

\section{Content System Based on Core Literacy School-Based Curriculum}

Based on the training objectives, the school constructs a school-based curriculum system based on core literacy and focuses on the cultivation of students' individuality. The relevant contents of the three-level courses of national, local and school-based curriculum will be integrated and streamlined, the basic courses required by the state will be fully implemented, and the curriculum reform will be vigorously carried out to meet the core literacy of students to form seven school-based curriculum systems. This truly realizes that "students have characteristics, school has vitality, and education has special features."

We implement reforms of different curriculums, such as through the "localization of the national curriculum", to construct high-quality classroom learning mode; through the "classification of the school curriculum", to establish a distinctive schoolbased curriculum and promote the growth of students' individuality; through the "clas- 
sification of practical activities" to create a quality school life. Therefore, the mainstream values of "advocating talents, promoting individuality, enhancing selfconfidence, and pursuing success" were realized to provide a broader space for students' individual and superior ability development.

\section{Classroom Teaching Reform for the Cultivation of Students' Core Literacy}

\section{Establish a "Student-Oriented" Classroom Teaching Concept}

In the school's education and development experience, students are the main participants, and the value orientation of students' spiritual pursuit and personality development is their development direction. According to the school's mainstream values as "advocating talent, enhancing self-confidence, promoting individuality, and pursuing success", the educational activities carried out by the school are unique and colorful. For instance, the military training, the parents Open House, the sunshine sports culture festival, the reading month, the walking inspiration between teachers and students, and "I am the champion", etc., and strive to provide student opportunities to build appropriate personality growth and comprehensive development. These educational activities are splendid, and the fruits are flourishing, showing the profound foundation of quality education.

The school advocates and practices "cultivating and forming one or two specialties and expertise" to train students in all aspects of physical and mental health, level of consciousness, personality quality, specialty expertise, and academic performance. Cultivate students to participate, be brave in competition, be fully displayed, passionate performance, show performance, be high spirits, self-confidence, and generosity. Through subject learning competitions, cadre campaigns, moderator selection, artistic talents, event organization, community activities, practical planning; "being the first", "I am the champion", subject competition, speech contest, military training, graduation and other ceremonies (entrance ceremony, etc.), life skills competitions, pottery art, art and technology festivals, sports meets, welcome parties, and commendation activities are the carriers to cultivate the value orientation and core accomplishment of students' independent development.

\section{Constructing a "Vibrant Growth" Classroom Teaching Model}

The structure of the course affects the quality of classroom teaching, and the quality of classroom teaching affects the quality of student accomplishment. On the basis of per- 
fecting the school-based curriculum system, the school advocates "energy classroom" and focuses on the "growth learning attitude" of the classroom to cultivate students" core literacy. The school practices the classroom teaching mode of "vigorous growth" by polishing various types of courses such as qualified courses, demonstration classes, and observation classes. This kind of classroom is the main front for implementing quality education, forming students' personality and developing students' core literacy.

The learning mode of "vigorous growth" classroom advocates that students combine learning knowledge with practical operation, and obtain knowledge as a carrier to develop "learning power" and "creativity". This teaching model includes the following aspects: vigor self-study questioning to cultivate students' ability to "focus on learning"; discussion and comprehension to cultivate students' ability to learn to solve problems effectively; display and sharing to train students' abilities of expression, thinking and speech, and systemic thinking, and thus cultivating students' leadership; testing and consolidating to give students a happy time of harvest, which helps them improve their happiness; evaluation and promotion, to achieve evaluation, promote learning level, and cultivate their self-confidence.

The "vigorous growth" classroom has established a new way of classroom learning. The quality, ability, talents and academics of the students have been comprehensively and effectively cultivated and improved. Individuals of different ages have developed vividly, energetically and fully. Every aspect of the "vigorous growth" classroom carries the responsibility of cultivating students' core literacy.

\section{Building Learning Groups}

Establishing a learning group helps to develop students' core literacy. The build-up of the learning group gives opportunity to everyone including teachers and students, and realizes a state that everyone is happy to participate, everyone can perform their duties, and everyone can interact. The quality of students is cultivated in the process of classroom learning, so as to realize the practical ability and innovative ability to solve problems in daily learning activities.

The changes in the organizational structure of students in the classroom, the changes in the way of teaching and learning, and the changes in the evaluation of classroom teaching effectively promote the active participation of all students in classroom learning activities, so that students are brave enough to undertake their tasks and responsibilities. Reasonably build class learning groups, fully mobilize the initiative, enthusiasm, persistence, cooperation and strong learning ability and collective learning, and enhance the sense of responsibility and the spirit of innovation, thus forming an organization that mobilizes and recognizes students themselves.

\section{Conduct Theme Education and Theme Activities}


The school carries out five "learning" series of education: learn to respect, learn to be grateful, learn to cherish, learn to cooperate, and learn to obey. At the same time, the school sponsored a series of theme activities: subject (learning) activities, talent show activities, team training activities, development training, and social practice activities. Through these activities, students are trained to be patient, proficient in skills, focus on accumulation, understanding limitations, adequate preparation, and attention to detail, calmness, independence, courage, state, and frustration.

Broaden the path and innovate the model of moral education, and establish multi-faceted, diversified and multi-field moral education activities. Combining the different ages, physical and mental characteristics, knowledge level and the development of morality of elementary and middle school students, closely related to the study and life practice of students of different grades, determine the fulcrum of moral education in different grades, and concentrate on the systematic education of moral education. We have a theme every month, and we have activities every week to implement an activity course centered on the activity experience (Table 2).

\section{Preliminary Results of School-Based Curriculum Ex- ploration}

According to the core literacy of students' development, combined with the actual situation of the school, the development of school-based curriculum, constructing a schoolbased curriculum system suitable for the development of students' core literacy, and creating opportunities for students' development through and through, has achieved initial achievements.

\section{Cultivate Interest in Learning and Improve Student Aca- demic Achievement}

The school builds an open learning space based on core-based school-based curriculum, focusing on interactive and immersive teaching. Students start from interest, "learning in playing" and "learning in doing". Everyone is their own master. Thinking, learning, and enjoying the happiness of learning improve their academic performance invisibly. Taking mathematics teaching as an example, the fifth-grade students' hand-painted mind maps, they seriously think about and carefully layout, effectively combing a certain knowledge point, forming a knowledge framework, and using it more freely, and displayed as an obvious improvement in academic performance of relevant knowledge.

\section{Develop a Variety of Abilities and Cultivate Students' Core Literacy}




\section{Table 2. Chengdu Qizhong Experimental School Theme Activities.}

\begin{tabular}{lll}
\hline Month & Theme & Main Activities \\
\hline September & $\begin{array}{l}\text { Thanksgiving } \\
\text { education }\end{array}$ & $\begin{array}{l}\text { "Teacher's Day" celebrations; " Mid-Autumn Festival } \\
\text { "thoughts and activities; } \\
\text { Parents' Open Day on September } 30 \text { (opening ceremony } \\
\text { for the first-year enrollment, opening of the class, opening } \\
\text { of the class, opening of the work, opening of the parent's } \\
\text { meeting, etc., parents visiting the school and attending } \\
\text { classes, exchanges, etc.) }\end{array}$ \\
\hline October & $\begin{array}{l}\text { Patriotic love } \\
\text { school educa- } \\
\text { tion }\end{array}$ & $\begin{array}{l}\text { I am adding color to the five-star red flag, striving to bend } \\
\text { over the seven real people, and caring for the campus envi- } \\
\text { ronment; }\end{array}$ \\
\hline November & $\begin{array}{l}\text { Talent educa- } \\
\text { tion }\end{array}$ & $\begin{array}{l}\text { Carry out the "I am the champion" student personality talent } \\
\text { contest; I am the speaker; carry out activities such as the } \\
\text { Sunshine Sports Culture Festival. }\end{array}$ \\
\hline December & $\begin{array}{l}\text { Character Edu- } \\
\text { cation }\end{array}$ & $\begin{array}{l}\text { Carry out character education activities such as learning to } \\
\text { be grateful, learning to cherish, learning to take responsibil- } \\
\text { ity, learning to be tolerant, and learning to cooperate. }\end{array}$ \\
\hline
\end{tabular}

Our school has a variety of school-based curriculum; students actively participate, experience in the experience, feel in the experience, enhance in the perception, and develop in the promotion. When more than 2,000 students in the elementary school learn ceramic art, students are interested and creative through kneading, splicing and shaping. The large group gymnastics performance at the opening ceremony of the Sunshine Sports Culture Festival, all students came on the scene, and exercised their ability to cooperate, coordinate, aesthetic and interact. The "Book Aroma Campus" speech contest, the ability of students to express, regulate, communicate and listen has been cultivated. Fire safety drills help students improve their self-rescue ability, making them more cherished. This series is based on a school-based curriculum that enhances students' core literacy, allowing students to forge core literacy in their experience - to benefit their physical and mental health, to cultivate aesthetic appeal, and to improve Practice and innovation capabilities.

\section{Focus on Curriculum Development and Promote Teacher Professional Growth}

In the school-based curriculum construction led by core literacy, teachers continue to study the students themselves, explore the existing resources, and effectively combine regional characteristics and superior culture to develop school-based curriculum suitable for the students of the school, which enriches the curriculum resources of the school. It strengthens the cultural heritage of students, helps students to develop personally, and promotes the professional development of teachers. For example, the art teacher inherits 
the ancient Chinese traditional skills, sets up a tie-dye school-based curriculum, sets up a "Light-Picking Staining Room" studio, uses a simple tool, a simple method of bundling, but interprets thousands of changes in tie-dyeing skills, which thereby cultivates students' unlimited imagination and creativity. Teachers think, teach and reflect in the whole process, while their teaching ability is improved, the ability to write school-based textbooks, and the ability to develop and research school-based curriculum has also been greatly improved.

Chengdu Qizhong Experimental School adheres to the aim of promoting the development of students, actively explores the core literacy school-based curriculum, strives to find the core of literacy, and trains students to form the necessary character and key ability to meet the needs of personal lifelong development and social development, and eventually trains students to be "take the world road with a Chinese heart".

\section{References}

Beijing Normal University Research Group (2016). Chinese students develop core literacy. People's Daily, 09.14.

Cai, Q. (2015). The core literacy of Taiwan's 12-year national basic education curriculum reform. Shanghai Edu Res, (4): 22-23.

Common core state standards initiative standards-setting criteria.

http://www.corestandards.org/aboutthestandards.2016.

Cui, Y. (2016). Asking "core literacy". Glob Edu Outlook, (05): 3-10+20.

Dou, G. (2017). The core literacy of students in the perspective of Chengzhi Education. People Edu, (Z1): 96-101.

European Commission / EACEA / Eurydice. Developing Key competences at School in Europe: Challenges and Opportunities for Policy. Eurydice Report. Luxembourg: Publications Office of the European Union.2012.
Gao, J. (2017). The connection between core literacy and moral education construction in primary and middle schools. Teach Edu, (26): 22-23.

He, S. (2019). "Five Rings Practice" highlights the cultivation of students' core literacy. Teacher Edu Forum (7th Srs), 07.

Lin, C. (2016). Research on the core literacy of student development in the 21st century. Beijing: Beijing Normal University Press, 22.

OECD. The definition of selection of key competencies: Executive summary.Pairs, France: centre for Educational Research and Innovation, 2015.

Shi, Z. (2018). Philosophical thinking on the core literacy of Chinese students' development. Cours Teach Mat Teach Meth, (09): 36-41.

Xing, X. (2019). School-based curriculum construction and implementation path based on differentiation strategy: taking 
primary and secondary schools as an example. J Yangtze Univ (Soc Sci Ed), (04):102-109.

Yan, H. (2016). The international vision of core literacy and China's position: the improvement of national quality and the transformation of educational objectives in China in the 21st century. Edu Res, (11): 8-18.

Zhang, Z. (2016). On the concept of literacy standard learning. Glob Edu Outlook, (03): 3-14.

Received: 10 June 2019

Revised: 28 July 2019

Accepted: 12 August 2019 